\title{
Viruses exacerbating chronic pulmonary disease: the role of immune modulation
}

\author{
Aran Singanayagam ${ }^{1,2}$, Priya $V$ Joshi $^{2}$, Patrick Mallia ${ }^{1,2}$ and Sebastian L Johnston ${ }^{1,2^{*}}$
}

\begin{abstract}
Chronic pulmonary diseases are a major cause of morbidity and mortality and their impact is expected to increase in the future. Respiratory viruses are the most common cause of acute respiratory infections and it is increasingly recognized that respiratory viruses are a major cause of acute exacerbations of chronic pulmonary diseases such as asthma, chronic obstructive pulmonary disease and cystic fibrosis. There is now increasing evidence that the host response to virus infection is dysregulated in these diseases and a better understanding of the mechanisms of abnormal immune responses has the potential to lead to the development of new therapies for virus-induced exacerbations. The aim of this article is to review the current knowledge regarding the role of viruses and immune modulation in chronic pulmonary diseases and discuss avenues for future research and therapeutic implications.

Keywords: Asthma, cystic fibrosis, chronic obstructive pulmonary disease, respiratory viruses, rhinovirus, interferon
\end{abstract}

\section{Introduction}

Chronic diseases are the leading cause of death worldwide and the third most common group of chronic diseases are chronic pulmonary diseases that account for an estimated four million deaths annually [1]. The most prevalent diseases of the respiratory tract are chronic obstructive pulmonary disease (COPD), asthma, tuberculosis and lung cancer, and the most common genetic disease is cystic fibrosis (CF). COPD is estimated to be the fourth leading cause of mortality by 2030 [2] and an estimated 300 million people suffer from asthma. COPD, asthma and CF are all

\footnotetext{
* Correspondence: s.johnston@imperial.ac.uk

'National Heart and Lung Institute, Imperial College London, Norfolk Place, London W2 1 PG, UK

Full list of author information is available at the end of the article
}

chronic inflammatory conditions but their etiology and pathogenesis differ markedly. COPD and asthma are believed to be caused by exposure to relevant environmental agents (mainly cigarette smoke and aeroallergens, respectively) in patients with a susceptible genetic background, whereas CF is caused by mutations in the $\mathrm{CF}$ transmembrane regulator gene. The typical clinical course of these conditions is of chronic symptoms that are punctuated by periods of increased symptoms termed 'acute exacerbations'. Acute exacerbations are now recognized to be significant events in the course of the disease and have enormous implications for patients, their caregivers and for healthcare providers. Exacerbations accelerate disease progression, impair quality of life, cause significant morbidity for patients and are the major cause of mortality. In addition they are the major drivers of excess healthcare costs as they often result in unscheduled healthcare visits, treatment costs and above all hospitalizations. Therefore, preventing exacerbations is a major therapeutic goal in all three diseases and one that has not been achieved with currently available treatments.

Despite the differences between COPD, asthma and $\mathrm{CF}$, all three have in common that respiratory virus infections are a major trigger of acute exacerbations. An important mechanism underlying this may be impaired host immune responses to virus infection and a better understanding of these mechanisms has the potential to lead to the development of new therapies that may be beneficial in different chronic pulmonary diseases. The aim of this article is to review the current knowledge regarding the role of viruses and host immune responses in asthma, COPD and CF, and discuss avenues for future research and therapeutic interventions.

\section{Induction of chronic respiratory diseases by viruses}

Although this article primarily focuses on acute exacerbations of chronic respiratory diseases, virus infection has also been implicated in the induction of asthma. Asthma is strongly related to a genetic predisposition to develop allergic reactions to aeroallergens. However, not
C Biomed Central

() 2012 Singanayagamn et al; licensee BioMed Central Ltd. This is an Open Access article distributed under the terms of the Creative Commons Attribution License (http://creativecommons.org/licenses/by/2.0), which permits unrestricted use, distribution, and reproduction in any medium, provided the original work is properly cited. 
all individuals with atopy develop asthma and, therefore, it has been proposed that other environmental factors may act as 'triggers' to the development of asthma in genetically susceptible individuals. One such factor that has attracted much research interest is respiratory virus infections, in particular infection with respiratory syncytial virus (RSV). In the majority of cases RSV causes a self-limiting upper respiratory tract infection, but in infants under the age of one year it can cause a more serious infection of the lower respiratory tract - bronchiolitis - and studies have linked RSV bronchiolitis with an increased frequency of subsequent wheezing and asthma [3]. Recently, it has been reported that rhinovirus (RV) infection is also related to the development of asthma [4]. However, these studies are unable to ascertain the direction of the relationship between viral infections and asthma, that is, whether infections cause asthma or infections occur more frequently in individuals predisposed to asthma. Recent evidence has emerged supporting the later hypothesis. A study using data on hospitalization due to RSV infection for all twins born in Denmark between 1994 and 2000 found that RSV hospitalization and asthma were positively associated but that a model in which asthma 'causes' RSV hospitalization fitted the data significantly better than a model in which RSV hospitalization 'causes' asthma [5]. A study of the temporal relationship between sensitization to aeroallergens and viral wheeze showed that allergic sensitization led to an increased risk of wheezing illnesses but viral wheeze did not lead to increased risk of subsequent allergic sensitization [6]. Therefore, the link between asthma and virus infection may be due to genetically determined alterations in airway or immune responses that predispose infants both to infection and asthma, rather than virus infections causing asthma [7]. This will be discussed later in light of recent developments regarding innate immune responses in asthma but it is clear that the relationship between respiratory virus infections and the induction of asthma is complex and requires further study.

\section{Asthma}

Asthma is the most common chronic respiratory disease affecting up to $10 \%$ of adults and $30 \%$ of children in the western world [8]. The Global Initiative for Asthma (GINA) defines asthma as 'a chronic inflammatory disorder of the airways in which many cells and cellular elements play a role. The chronic inflammation is associated with airway hyperresponsiveness that leads to recurrent episodes of wheezing, breathlessness, chest tightness, and coughing, particularly at night or in the early morning. These episodes are usually associated with widespread, but variable, airflow obstruction within the lung that is often reversible either spontaneously or with treatment'. This definition refers to the key physiological marker of asthma
- reversible airflow obstruction, and the key pathological characteristic - airways inflammation. The characteristic pattern of inflammation of allergic diseases and also in asthma involves eosinophils, mast cells and $\mathrm{T}$ helper 2 lymphocytes (Th2) and a wide range of inflammatory mediators. Asthma exacerbations are episodes characterized by progressive increase in shortness of breath, cough, wheezing and chest tightness, or some combination of these, and increased airflow obstruction that is manifested by reductions in measurements of lung function such as peak expiratory flow (PEF). Acute exacerbations are a common occurrence in asthma and the social and economic burden of asthma exacerbations is substantial, due to both the direct costs of healthcare utilization and the indirect costs associated with lost productivity. Current therapies for asthma consist of bronchodilator and antiinflammatory medications, the mainstay of which are inhaled $\beta_{2}$-agonists and inhaled corticosteroids, respectively. These are highly effective in relieving symptoms and reduce exacerbations by approximately $50 \%$ in clinical trials [9]. However, in 'real life' surveys of asthmatics a significant proportion of patients continue to experience acute exacerbations despite therapy and, therefore, prevention/treatment of exacerbations remains a major unmet clinical need in asthma [10-12].

\section{Viruses and asthma exacerbations}

It has long been recognized that viral respiratory tract infections are triggers for exacerbations of asthma in both adults and children but early studies reported low detection rates of viruses in asthma exacerbations casting doubt on this association. The development of highly sensitive and specific molecular diagnostic techniques using polymerase chain reaction (PCR) technology led to a reappraisal of the role of virus infections in asthma. Studies using PCR detected viruses in approximately $80 \%$ to $85 \%$ of asthma exacerbations in school-aged children and $60 \%$ to $80 \%$ of exacerbations in adults. Although respiratory virus infection can be detected in stable asthma patients detection rates are consistently lower than in exacerbated patients $[13,14]$. Therefore, these studies suggest that the majority of asthma exacerbations are associated with respiratory virus infections and that the low detection rates in earlier studies were a consequence of diagnostic methods with a low sensitivity. The most common viruses detected in these studies were RV. RVs are members of the picornaviridae family and are the most common cause for the common cold in both children and adults. More than 100 serotypes exist. Virus typing classified RVs into RV-A and RV-B groups based on susceptibility to anti-viral drugs and on genetic sequence similarity. More recently a newly identified group termed RV-C has been identified based purely on sequencing data [15]. Other respiratory viruses have been 
detected in subjects with asthma exacerbations including influenza, RSV, coronaviruses, human metapneumoviruses, parainfluenza viruses (PIV) and adenoviruses. However, in a recent study in children the only virus type significantly associated with asthma exacerbations was RV [16]. The risk of exacerbation following virus infection is influenced by other factors such as allergy and environmental pollution. Allergen sensitization, exposure to sensitizing allergens, and respiratory virus infection act in a synergistic manner to significantly increase the risk of hospitalization with acute asthma in both adults [17] and children [18]. The presence of high ambient levels of nitric oxide $(\mathrm{NO})$ is also associated with an increased risk of exacerbation following RV infection [19].

\section{Understanding the mechanisms of virus-induced exacerbations is important for treatment strategies}

Following discovery of the role of RV in asthma exacerbations research attention has focused on the mechanisms of susceptibility to virus infection in asthmatics. RV infection in healthy individuals results in a predominantly upper respiratory symptom syndrome ('common cold'), whereas in asthmatics infection results in lower respiratory symptoms and airflow obstruction ('acute exacerbation'). A study of co-habiting partners discordant for the presence of asthma demonstrated that asthmatics do not have a higher frequency of RV infections but have more severe lower respiratory symptoms and changes in airway physiology [20]. Similar results have been reported in experimental RV infection studies in asthmatics and nonasthmatic control subjects [21]. Therefore, it would appear that the consequences of virus infection in asthmatics are more severe than in non-asthmatics. Understanding the mechanisms underlying increased disease severity is crucial to developing new strategies to treat virus-induced exacerbations.

\section{Biology of rhinovirus infection}

Most research into virus-induced asthma exacerbations has focused on RV as these are the most common viruses detected in asthma exacerbations and well-characterized models of RV infection exist both in vitro and in vivo. RVs primarily enter and replicate in epithelial cells in the respiratory tract and trigger a cascade of immune and inflammatory responses. Following viral entry into a cell, uncoating of the virus leads to the release of viral RNA that is recognized by pattern recognition receptors including toll-like receptors (TLR)-3, -7 and -8 , and the cytosolic RNA helicases, retinoic acid inducible gene I (RIG-I) and melanoma differentiation-associated protein5 (MDA-5) [22,23]. The interactions between ligand and receptor trigger signaling cascades ultimately resulting in the activation of transcription factors such as interferon regulatory factor (IRF)-3 and-7, nuclear factor- $\kappa \mathrm{B}$ (NF- $\kappa \mathrm{B})$ and activating transcription factor 2 (ATF2). These activated transcription factors translocate to the nucleus and induce transcription of the type I interferons (IFN- $\alpha$ and $-\beta$ ) and pro-inflammatory cytokines including interleukin (IL)-8/CXCL8, IL-6, epithelial-derived neutrophilactivating peptide 78 (ENA-78/CXCL5) and IFN- $\gamma$ induced protein $10 \mathrm{kDa}$ (IP-10/CXCL10)[24-28]. IFN- $\alpha$ and $-\beta$ have both a direct antiviral effect through inhibition of viral replication in cells and an indirect effect through stimulation of innate and adaptive immune responses. The direct antiviral activity of type I IFNs is mediated by various mechanisms including blocking viral entry into cells, control of viral transcription, cleavage of RNA and blocking translation. These effects are mediated through the up-regulation of interferon stimulated genes (ISGs) and the production of antiviral proteins. The indirect antiviral effect is mediated through induction of natural killer cell cytotoxicity [29], up-regulation of the expression of major histocompatibility complex 1 (MHC1) on cells and up-regulation of co-stimulatory molecules on antigen-presenting cells. Therefore, a robust interferon response is central to effective antiviral responses and resolution of virus infections. Recently a novel class of interferons termed type III interferons, or interferonlambda (IFN- $\lambda$ ) has been described. The type III IFNs consist of IFN- $\lambda 1$, 2, 3 (respectively, IL-29, IL-28A and IL-28B) [30]. The IFN- $\lambda$ s utilize a different receptor than IFN- $\alpha / \beta$ but appear to have functional similarities, however much more is known about the mechanism of action of IFN- $\alpha / \beta$.

The pro-inflammatory mediators and cytokines induced by RV infection lead to chemoattraction of inflammatory cells such as neutrophils, lymphocytes and eosinophils. This inflammatory response contributes to virus clearance but is also responsible for the pathology induced by RV infections. The balance between antiviral and inflammatory responses following virus infection is likely to determine the clinical outcome of the infection. An effective antiviral response rapidly controls viral replication with a minimal inflammatory response and limited clinical illness. If antiviral responses are inadequate this is likely to result in uncontrolled viral replication, greater inflammatory response and more severe clinical illness (Figure 1). The evidence that clinical illness following virus infection is more severe in asthmatics has stimulated research into possible dysregulation of antiviral and inflammatory responses in asthmatics.

\section{Inflammatory and immune responses to virus infection in asthma}

In 2005 Wark et al. examined the kinetics of virus replication in bronchial epithelial cells obtained from asthmatics and healthy volunteers and reported that viral replication is increased in cells from asthmatics 


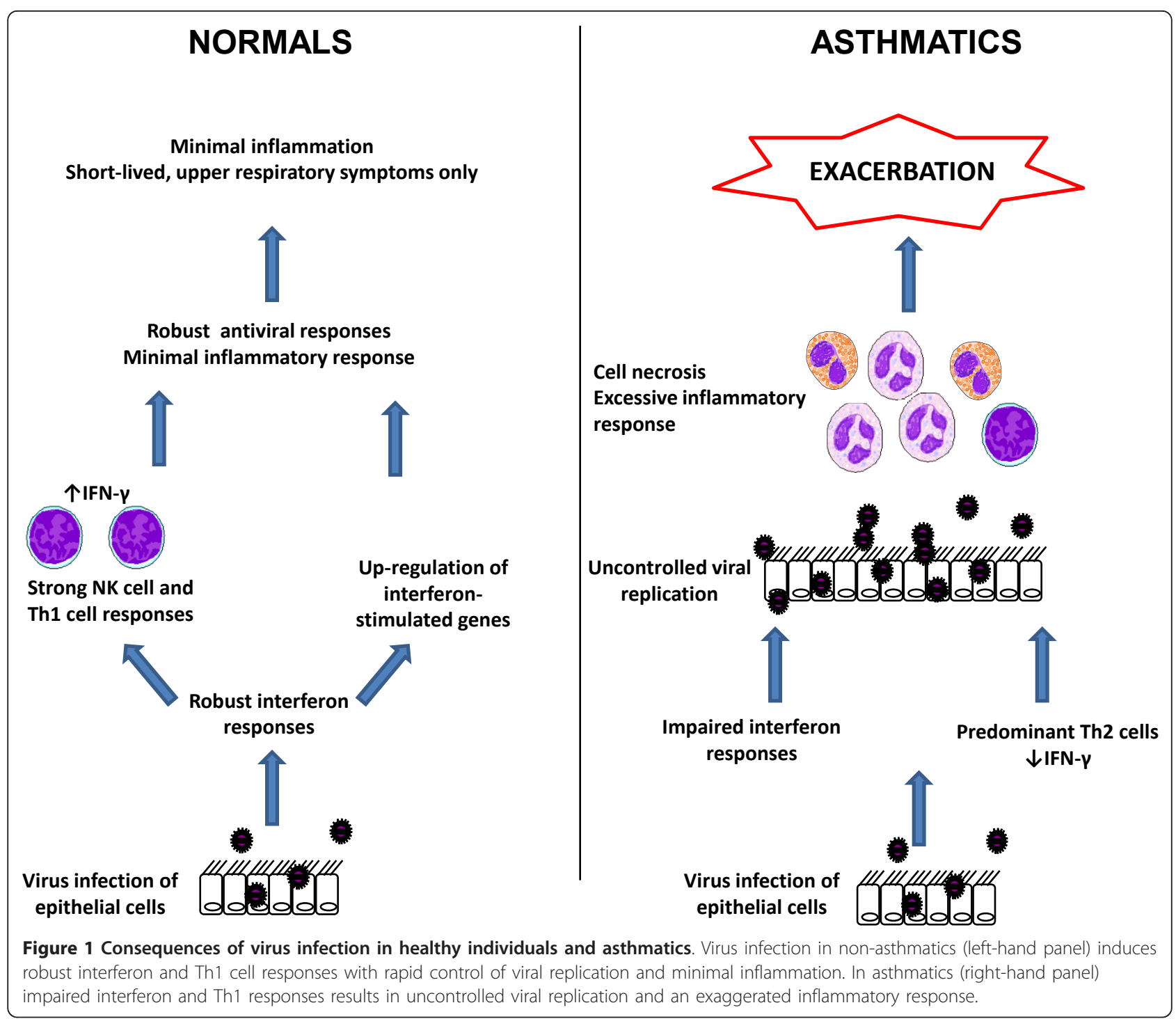

compared to non-asthmatic subjects [31]. This was the first report indicating that the innate immune response to virus infection may be impaired in asthma. Furthermore, the authors demonstrated that production of IFN$\beta$ was impaired in asthmatics and administration of exogenous IFN $-\beta$ resulted in restoration of a normal antiviral response, and this was confirmed in a subsequent study [32]. Deficient IFN- $\beta$ production by bronchial epithelial cells [33], as well as deficient IFN- $\alpha$ production by peripheral blood mononuclear cells [34-36] and dendritic cells [37] has also been reported in asthma. Our group has also shown that IFN- $\alpha$ and IFN- $\beta$ production by alveolar macrophages is impaired in asthmatics (manuscript submitted). Furthermore, deficient IFN $-\lambda$ production by epithelial cells and alveolar macrophages in asthmatics has also been reported and related to clinical outcomes following experimental RV [38].
However, other groups have not reported deficient IFN induction in epithelial cells from asthmatics [39,40]. In experimental RV infections virus loads were higher and virus shedding prolonged in asthmatics but this was not statistically significant $[21,41]$. Therefore, although interferon deficiency is an exciting new mechanism underlying increased severity of virus infection in asthma it has not been conclusively demonstrated to occur in all asthmatic subjects studied. The studies in question were small with different experimental conditions such as cell culture techniques and virus dose. It is also possible that interferon deficiency occurs in some asthmatics only and it may also be related to disease severity, disease control or degree of atopy. Further studies with more subjects and careful patient selection and characterization are required to provide answers to these ongoing research questions. 
If interferon production in response to virus infection is impaired in asthmatics what are the possible molecular mechanisms underlying this? The discovery that IFN- $\alpha$, IFN- $\beta$ and IFN- $\lambda$ are all deficient suggests that it is not a genetic defect as IFN- $\alpha$ and IFN- $\beta$ are on different genetic loci than IFN- $\lambda$. A key family of proteins regulating both interferon production and allergic inflammation are the suppressor of cytokine signaling family (SOCS), and one member of this family, SOCS1, is a potent negative regulator of type I and type II interferons and of Th2 inflammation $[42,43]$. SOCS1 is induced by type II cytokines such as IL-13 [44] and, therefore, persistent Th2 inflammation may result in chronic up-regulation of SOCS1 and impaired interferon responses, but this hypothesis requires further investigation.

\section{Inflammatory responses to virus infection in asthma}

In vitro infection of airway epithelial cells with $\mathrm{RV}$ induces the production of inflammatory mediators and this has also been reported in vivo in both experimental and naturally-acquired viral infections. Chemokines and cytokines such as IL-8, IL-6 and regulated on activation, normal T-cell expressed and secreted (RANTES) have been detected during virus infections in asthmatic patients [45-49]. However it remains unclear whether the inflammatory response following virus infection differs quantitatively or qualitatively in asthmatics. One experimental RV infection study reported increased nasal lavage levels of IL- 8 and IL-1 $\beta$ in asthmatics [46] but not in control subjects; however, another study reported no differences in IL-6, IL-8, IL-11 and granulocyte-monocyte-colony stimulating factor (GM-CSF) levels in either nasal lavage or sputum between asthmatics and nonasthmatics [45]. Increased sputum levels of IL-10 but not RANTES or IL-8 have been reported in asthmatics [48]. These conflicting results highlight the need for further studies evaluating the inflammatory profile (preferably in the lower airway) in well-characterized patients and nonasthmatic controls following virus infection.

Many of the inflammatory mediators produced are chemoattractants and, therefore, following virus infection inflammatory cells are recruited to the lungs. A number of different inflammatory cells have been identified in both naturally-occurring and experimental virus infections in asthma. Although stable asthma is characterized by eosinophilic inflammation, a number of studies have identified neutrophils as the key inflammatory cell in virus-induced asthma exacerbations [21,50-52]. Neutrophils release bioactive mediators such as the protease neutrophil elastase that have effects such as stimulation of mucous production and, therefore, are likely key contributors to the pathogenesis of asthma exacerbations. Another key cell involved in immune and inflammatory responses in the lungs is the macrophage. There is evidence that RVs can infect macrophages and that in asthmatics macrophage responses to virus infection are altered. Our group has reported that RVs infect macrophages and induce TNF- $\alpha$ production [53] and that production of the cytokine IL-15, that plays a key role in linking innate and adaptive antiviral immune responses and promoting $\mathrm{T}$ cell anti-viral immune responses, is impaired in asthmatics [53]. As described previously, macrophage production of IFNs in response to virus infection is also impaired in asthma [38]. Therefore, there is evidence of impaired antiviral responses in asthmatics in macrophages as well as respiratory epithelial cells.

Increased lymphocyte numbers in bronchoalveolar lavage (BAL) and bronchial biopsies in experimental RV infection in asthmatics has been reported, with increases in CD4+, CD8+ and NK cells [21,54]. Abnormalities of the acquired immune system in stable asthma have been well described with skewing of acquired immune responses towards a Th2 profile. As robust antiviral responses require an adequate Th1 response it is possible that in diseases such as asthma with predominant Th2 cells antiviral immunity is impaired. Impaired levels of the Th1 cytokines IL-12, -15, -18 and IFN- $\gamma$ have all been reported in asthma [21,55-57]. In human experimental RV infection lower respiratory symptoms, bronchial hyperreactivity, reductions in blood total and CD8+ lymphocytes and virus load are related to deficient IFN- $\gamma$, IL-12 or IL-15 responses and to augmented IL-4, IL-5, and IL-13 responses [21,55]. Sputum IFN- $\gamma / \mathrm{IL}-5$ messenger RNA ratio following virus infection is inversely related to both peak cold symptoms and the time to viral clearance [58]. Therefore, augmented Th2 and deficient Th1 immune responses are associated with greater clinical illness following RV in asthma.

\section{Induction of asthma}

The identification of impaired innate immunity in asthma suggests a possible mechanism not only for virus-induced asthma exacerbations but also for the link between respiratory virus infections and the subsequent development of asthma. It is possible that infants who will develop asthma in later life have impaired immune responses from birth and, therefore, are more likely to develop more severe disease manifestations (for example, bronchiolitis) following respiratory virus infection. Most studies to date have focused on the role of the acquired immune system and identified reduced IFN- $\gamma$ production as a significant risk factor both for subsequent wheezing illness and allergic sensitization [59-61]. No studies have investigated innate immune responses in infants prior to the development of symptomatic asthma but impaired IFN- $\alpha$ production has been reported in older children with atopic asthma [35].

In conclusion there is evidence that both innate and acquired immune responses in asthmatics are impaired 
and this may be a key mechanism underlying virusinduced asthma exacerbations and the link between virus infections and the subsequent development of asthma in infants. Further studies are needed to determine whether these deficiencies are common to all asthmatics, whether they represent a specific asthma phenotype and how they relate to conventional measures of asthma control. Another important research question is whether new interventions targeting the interferon pathways can prevent asthma exacerbations and even potentially prevent the development of asthma in infants.

\section{Chronic Obstructive Pulmonary Disease}

Chronic obstructive pulmonary disease (COPD) is the most common chronic respiratory condition in adults. The Global Initiative for Obstructive Lung Disease (GOLD), a collaboration between the World Health Organization and the National Heart Lung and Blood Institute, defines COPD as 'a preventable and treatable disease with some significant extrapulmonary effects that may contribute to the severity in individual patients. Its pulmonary component is characterized by airflow limitation that is not fully reversible. The airflow limitation is usually progressive and associated with an abnormal inflammatory response of the lung to noxious inhaled particles or gases' [62]. The main etiological agents linked with COPD are cigarette smoking and biomass exposure and the inflammatory response consists of neutrophils, macrophages and CD8+ T cells and, therefore, differs from the allergic inflammation seen in asthma. Pulmonary inflammation is further amplified by oxidative stress and excess proteases released by inflammatory cells recruited to the lung. As in asthma, acute exacerbations are a common occurrence in COPD and become more frequent as the disease progresses [63]. Exacerbations are a major cause of morbidity, mortality and healthcare costs and accelerate decline in lung function [64] and quality of life [65] in COPD patients. Historically, bacterial infections have been considered the predominant infectious etiology, however epidemiological data showing a greater frequency of exacerbations in the winter months [66] and frequent coryzal symptoms preceding exacerbations suggest a causal role for viruses [67]. Older studies using cell culture and serologic diagnostic tests detected viral infection in only approximately $10 \%$ to $20 \%$ of exacerbations $[68,69]$. However, these diagnostic methods have low sensitivity for virus detection especially for RVs that are the most common cause of upper respiratory tract infections. More recent studies using modern PCR-based techniques have allowed a re-evaluation of the importance of viruses in COPD exacerbations and these studies have shown the presence of viruses in $47 \%$ to $56 \%$ of exacerbations [70-73]. A recent systematic review evaluated weighted mean prevalence of respiratory viruses detected by PCR in patients with acute exacerbations of COPD. Eight studies were included with an overall prevalence of $34.1 \%$, with picornaviruses including RVs being the most frequently detected pathogen, followed by influenza, parainfluenza, RSV and adenoviruses [74]. Although these studies have higher detection rates they are likely to have underestimated the role of viral infections in COPD exacerbation as they evaluated patients at the time of presentation to healthcare services which often occurs considerably later than the onset of exacerbation and by which time virus may no longer be detectable.

\section{Experimental infection studies in COPD}

Although viruses are frequently detected in COPD exacerbations, their presence during exacerbations does not prove a definite causative role. Experimental infection using RV provides a novel tool for investigating relationships between virus infection and exacerbations. Such studies have been previously conducted in asthma and yielded important insights into the mechanisms linking virus infection to exacerbations in asthma. A recent study from our group reported the first experimental RV infection study in COPD [75]. COPD patients and nonobstructed controls were infected with RV with sequential measurement of symptoms, lung function, inflammatory markers and virus load. Following RV infection, COPD subjects developed symptomatic colds followed by the typical lower respiratory symptoms of an acute exacerbation. Symptoms were accompanied by objective evidence of airflow limitation and airways inflammation and inflammatory markers correlated with virus load. Virus was detected in airway samples prior to the onset of symptoms and viral clearance was followed by symptom resolution and return of inflammatory markers to baseline levels. Therefore, this study directly links respiratory virus infection to lower respiratory symptoms, airflow obstruction and airways inflammation in COPD and provides novel evidence supporting a causative role for RV infection in COPD exacerbations.

\section{Mechanisms of virus-induced COPD exacerbations}

Much less is known regarding mechanisms of virusinduced exacerbations in COPD compared to asthma. In the experimental infection study, symptoms, airflow obstruction and airways inflammation were more severe in the COPD subjects compared to non-obstructed controls [75]. Therefore, as is the case in asthma it would appear that clinical illness following RV infection is more severe in COPD subjects, but the mechanisms underlying this are poorly understood. COPD exacerbations are associated with increased levels of inflammatory mediators including tumor necrosis factor-alpha (TNF- $\alpha$ ) [76], IL-8 [76,77], IL-6 [78], and leukotriene B4 [79] and 
inflammatory cells such as neutrophils [70,77] and eosinophils [70]. However, few studies have examined the inflammatory response specific to virus-induced exacerbations. Virus infection has been associated with high levels of IL-6 $[80,81]$ and IP-10 $[82,83]$ and Papi et al. reported that elevated sputum eosinophils were only seen in exacerbations in which a virus was present [70]. Others have reported that the presence of RV is not associated with significant airway inflammation [84] and that only exacerbations associated with purulent sputum (presumed bacterial infection) are associated with airways inflammation [79]. From the data available no clear conclusions can be drawn regarding the inflammatory response to virus infection in COPD and there are no studies comparing the effects of naturally-occurring virus infections in COPD patients and non-COPD controls.

There is evidence from animal models that the inflammatory response to virus infection may be exaggerated in COPD. In a mouse model of COPD utilizing intranasal administration of lipopolysaccharide and elastase, infection with RV resulted in increased levels of TNF- $\alpha$ and IL-13 compared to control mice [85]. This was accompanied by increased airway hyper-responsiveness and increased mucus production. Similarly, in the human COPD RV challenge study, increased levels of IL-8 and neutrophil elastase were reported in COPD subjects when compared to non-obstructed controls [75]. These studies suggest that COPD is associated with an exaggerated inflammatory response to viral infection and this may explain the increased severity and duration of symptoms seen in these patients.

In vitro studies have shown that cigarette smoke impairs release of IFN $-\beta$ and IFN- $\alpha$ [86]. BAL cells from COPD patients infected ex vivo with RV demonstrated deficient induction of IFN- $\beta$ with similar trends for deficient induction of IFNs- $\alpha$ and $-\lambda$, associated with deficiency of the interferon stimulated gene CXCL10 [75]. Similar findings have been reported in a mouse model where persistence of $\mathrm{RV}$, increased airways inflammation and deficient induction of IFNs- $\alpha,-\beta$ and $-\gamma$ were reported in COPD mice compared to controls [85]. However in vitro RV infection of epithelial cells from COPD patients resulted in higher virus load and increased inflammatory mediators, but no differences in interferon production compared to cells from control subjects [87]. Further studies examining the role of interferon deficiency in viral exacerbations are required as this may lead to potential future therapeutic application of interferon therapy in reducing exacerbation severity in COPD. RVs bind to cells via intercellular adhesion molecule-1 (ICAM-1, major group RVs) or members of the low-density lipoprotein receptor family (minor group RVs). ICAM-1 is upregulated on the bronchial epithelium of patients with COPD $[87,88]$ and, therefore, it is possible that increased ICAM-1 levels may permit greater virus binding and increased viral entry into epithelial cells in COPD patients.

\section{Virus infection and stable COPD}

The majority of studies have detected viruses at a greater frequency during acute exacerbations compared to the stable state. One study indicated that RSV is detected in nasal lavage at a similar frequency of around $25 \%$ in the stable state and during exacerbations [67]. This was followed by a similar study reporting detection of RSV in about $30 \%$ of sputum samples, with detection being related to greater airway inflammation and to a faster decline in lung function [89]. However, other studies have not reported increased RSV detection in stable COPD $[70,71]$. A study comparing virus loads between infants with acute respiratory infections and adult COPD patients found that virus loads were 2000-fold higher in the infants, suggesting low-grade virus infection in COPD [90]. The disparity between these findings is likely to be due to a combination of factors including differing sensitivity of the PCR techniques used, differences in severity of COPD patients included or differences in the populations studied [91].

Latent infection by adenovirus has also been proposed to be involved in the pathogenesis of COPD. Lung tissue from COPD patients has been demonstrated to carry more group $C$ adenoviral DNA than matched nonobstructed smokers [92]. Latent adenoviral infection in combination with cigarette smoke exposure in a guinea pig model caused an increase in lung volumes, airspace volume and reduced surface to volume ratio compared to smoke exposure alone [93]. Additionally, adenovirus detection has been shown to be similar in exacerbated and stable COPD patients [94]. Some authors have postulated that the presence of RSV and adenovirus in stable COPD may contribute to the pathogenesis of the disease as there are some common pathologic features between respiratory viral infection and COPD including a predominance of CD8+ T lymphocytes. However, this remains a largely unproven hypothesis.

\section{Cystic Fibrosis}

Cystic fibrosis (CF) is an autosomal recessive disease caused by mutations in the gene for the cystic fibrosis transmembrane regulator (CFTR) protein. Defective CFTR function leads to abnormal transport of chloride and sodium across the pulmonary epithelium, resulting in viscous secretions in the lungs, recurrent bacterial infections and progressive loss of lung function. Pulmonary involvement is the most common manifestation of the disease and respiratory failure the most common cause of death. Respiratory infections are the leading cause of morbidity, decline in lung function and hospitalizations due to acute exacerbations. The major cause of 
infectious complications in CF has always been considered to be bacterial infection, with Pseudomonas aeruginosa the most common organism detected. There has been relatively little research on the role of virus infections in CF but recent studies have suggested that viruses have a significant impact on the CF patient.

\section{Viruses and $\mathrm{CF}$ exacerbations}

The role of respiratory viruses in CF exacerbations is likely to have been under-appreciated in the past because older studies investigated only one virus type and the detection methods used were not sufficiently sensitive. Newer PCR techniques have helped to improve detection and it is now becoming clear that viruses are implicated in exacerbations in CF. Previous studies using serology, culture and immunoflourescence detected viruses in $10 \%$ to $28 \%$ of exacerbations in CF patients [95-98]. In contrast, studies using PCR for virus detection have reported detection rates of $50 \%$ to $60 \%$ [99-101]. A number of different viruses have been detected in CF patients with the most common being RVs, influenza and RSV. The incidence of viral infections in children with CF is not elevated in comparison to healthy children but the severity of clinical illness associated with infection is greater [102]. Viral infections are associated with deterioration in lung function and more severe clinical illness indicating that they contribute to disease progression thus demonstrating the clinical importance of research within this field $[100,103]$.

\section{Mechanisms of virus infection in CF}

The mechanisms of viral-induced CF exacerbations and increased clinical illness are poorly understood with conflicting results from published studies. Some authors have reported increased production of pro-inflammatory cytokines and chemokines by epithelial cells obtained from CF patients compared to healthy controls [102,104]. However, others have failed to detect any differences in cytokine production between CF and normal cells $[105,106]$. These differences may be due to different viruses used (RV, RSV, PIV) and differences in cell culture techniques, but it remains unclear whether the CF epithelium is intrinsically pro-inflammatory in response to virus infection. Another mechanism that has been postulated is a deficiency in antiviral innate immune responses in CF cells. Increased replication following PIV infection of CF cells has been reported and this was corrected by administration of IFN$\alpha$ [102]. IFN responses were not impaired but induction of nitric oxide synthase 2 (NOS2) was impaired in CF. NOS2 is required for production of $\mathrm{NO}$ that has potent antiviral effects and, therefore, impaired NO synthesis may be one mechanism of impaired antiviral host responses in CF. Our group has reported reduced IFN- $\beta$ and IFN- $\lambda$ production and reduced ISGs in CF epithelial cells [107] and, therefore, IFN deficiency may be relevant to CF as well as in asthma and COPD. Holtzman has proposed that "hypersusceptibility' to virus infection, via defective interferon pathways, is a unifying pathway in asthma, COPD and now CF [108].

\section{Bacteria-virus interactions in pulmonary disease}

Both bacterial and virus infections are common in $\mathrm{CF}$ and COPD and, therefore, co-infections are likely to be common. There is now increasing evidence that both viral and bacterial infections can modulate host immune responses and increase susceptibility to subsequent infection. There is abundant evidence from both human studies and animal models that influenza infection impairs antibacterial immunity and this can result in secondary bacterial pneumonia $[109,110]$. However, much less is known regarding the effect of other respiratory viruses, such as RVs, on susceptibility to bacterial infection. In vitro studies have reported that RV infection increases bacterial adhesion to epithelial cells [111-113] and impairs macrophage immune responses to bacterial products [114]. We have found that experimental RV infection in COPD is followed by secondary bacterial infection in $60 \%$ of patients and this is related to deficiency of the antimicrobial peptides elafin and secretory leukoprotease inhibitor (SLPI) (submitted manuscript). There are also studies indicating that virus-bacteria interactions influence host immune responses in CF. Chattoraj et al. reported that RV infection of CF cells liberates planktonic bacteria from biofilm [115]. Planktonic bacteria express virulence factors and stimulate inflammatory responses more readily compared to biofilm bacteria and this was manifested by increased cytokine responses. Evidence is also emerging that bacterial infection can increase susceptibility to viral infection. Infection of epithelial cells by Haemophilus influenzae (a common organism in COPD) increases susceptibility to infection by RV, possibly by up-regulation of ICAM-1 [116]. CF cells infected with mucoid P.aeruginosa and then with RV produced less IFN and viral loads were higher compared to cells infected with the RV alone [117]. This effect was not seen in normal epithelial cells infected with Pseudomonas and was related to the inhibition of Akt phosphorylation and IRF-3 activation - both prerequisites for the IFN response to RV infection.

It is widely acknowledged that the main infectious cause of asthma exacerbations is virus infection and it is believed that bacteria play only a minor role. However, a recent study using culture-independent molecular methods for bacterial detection reported that the bacterial flora in the airways of asthmatics is closer to that of COPD patients than of non-asthmatics [118]. The role of bacteria in asthma exacerbations needs to be revisited as 
virus-bacterial interactions may play a role in the pathogenesis of asthma exacerbations. This is a fertile area for further research.

Our knowledge of the interactions between respiratory viruses and bacteria, and how these influence host immune responses in pulmonary diseases, is still at an early stage. Further research is required to understand better these complex relationships and to explore the implications they may have for the development of new therapies.

\section{Conclusions}

There is now convincing data implicating respiratory viruses as a major cause of acute exacerbations in asthma, COPD and CF. In all these conditions there is evidence that host immune responses to virus infection are impaired, but whether this occurs through a common mechanism, or whether mechanisms differ between the different diseases is unclear. Further research is needed to elucidate the exact mechanisms of increased susceptibility to virus infection in pulmonary diseases, the interactions between viruses and bacteria and how these impact on host immune responses. A better understanding of these mechanisms has the potential to lead to the development of novel therapies that will reduce the impact of acute exacerbations in chronic pulmonary diseases.

\section{List of abbreviations}

ATF: activating transcription factor; BAL: bronchoalveolar lavage; CF: cystic fibrosis; CFTR: cystic fibrosis transmembrane regulator; COPD: chronic obstructive pulmonary disease; ENA-78: epithelial-derived neutrophilactivating peptide 78; ICAM-1: intercellular adhesion molecule; IFN-a: interferon-alpha; IFN- $\beta$ : interferon-beta; IFN- $\lambda$ : interferon-lambda; IFN- $\gamma$ : interferon-gamma; IL: interleukin; IP-10: IFN- - -induced protein-10; IRF: interferon regulatory factor; ISG: interferon stimulated genes; MDA-5: melanoma differentiation-associated protein-5; NF-kB: nuclear factor-kappa B; NO: nitric oxide; NOS2: nitric oxide synthase 2; PCR: polymerase chain reaction; PEF: peak expiratory flow; PIV: parainfluenza virus; RANTES: regulated on activation: normal T-cell expressed and secreted; RIG-I: retinoic acid inducible gene I; RSV: respiratory syncytial virus; RV: rhinovirus; SLPI: secretory leukoprotease inhibitor; SOCS: suppressor of cytokine signaling family; Th1/2: T helper 1/2; TLR: toll-like receptors; TNF-a: tumor necrosis factor-alpha -1.

\section{Acknowledgements}

This work was supported by the National Institute of Health Research, the Medical Research Council and Asthma UK.

\section{Author details}

${ }^{1}$ National Heart and Lung Institute, Imperial College London, Norfolk Place, London W2 1PG, UK. ${ }^{2}$ Imperial College Healthcare NHS Trust, Praed Street, London W2 1NY, UK.

\section{Authors' contributions}

All the authors contributed equally to writing the manuscript. All authors read and approved the final manuscript.

\section{Authors' information}

SLJ heads a group working on mechanisms of asthma and chronic obstructive pulmonary disease and the role of respiratory viral infections in these diseases, with a particular interest in acute exacerbations and the role of rhinovirus infections. PM and AS work in his group with a particular focus on human and mouse models of virus infection in COPD. PVJ works in the Department of Respiratory Medicine at Imperial College NHS Healthcare Trust.

\section{Competing interests}

SLJ has patents on the use of interferons as a treatment for asthma exacerbations and COPD exacerbations and share options in Synairgen. AS, PVJ, and PM declare that they have no competing interests.

Received: 2 November 2011 Accepted: 15 March 2012

Published: 15 March 2012

\section{References}

1. Yach D, Hawkes C, Gould CL, Hofman KJ: The global burden of chronic diseases: overcoming impediments to prevention and control. JAMA 2004, 291:2616-2622.

2. Mathers $C D$, Loncar D: Projections of global mortality and burden of disease from 2002 to 2030. PLoS Med 2006, 3:e442.

3. Sigurs N, Bjarnason R, Sigurbergsson F, Kjellman B: Respiratory syncytial virus bronchiolitis in infancy is an important risk factor for asthma and allergy at age 7. Am J Respir Crit Care Med 2000, 161:1501-1507.

4. Jackson DJ, Gangnon RE, Evans MD, Roberg KA, Anderson EL, Pappas TE, Printz MC, Lee WM, Shult PA, Reisdorf E, Carlson-Dakes KT, Salazar LP, DaSilva DF, Tisler CJ, Gern JE, Lemanske RF Jr: Wheezing rhinovirus illnesses in early life predict asthma development in high- risk children. Am J Respir Crit Care Med 2008, 178:667-672.

5. Thomsen SF, van der Sluis S, Stensballe LG, Posthuma D, Skytthe A, Kyvik KO, Duffy DL, Backer V, Bisgaard H: Exploring the association between severe respiratory syncytial virus infection and asthma: a registry- based twin study. Am J Respir Crit Care Med 2009, 179:1091-1097.

6. Jackson DJ, Evans MD, Gangnon RE, Tisler CJ, Pappas TE, Lee WM, Gern JE, Lemanske RF Jr: Evidence for a causal relationship between allergic sensitization and rhinovirus wheezing in early life. Am J Respir Crit Care Med 2012, 185:281-285

7. Stein RT, Martinez FD: Respiratory syncytial virus and asthma: still no final answer. Thorax 2010, 65:1033-1034.

8. Masoli M, Fabian D, Holt S, Beasley R: The global burden of asthma: executive summary of the GINA Dissemination Committee report. Allergy 2004, 59:469-478.

9. Pauwels RA, Lofdahl CG, Postma DS, Tattersfield AE, O'Byrne P, Barnes PJ, Ullman A: Effect of inhaled formoterol and budesonide on exacerbations of asthma. Formoterol and Corticosteroids Establishing Therapy (FACET) International Study Group. N Engl J Med 1997, 337:1405-1411.

10. Moore WC, Bleecker ER, Curran-Everett D, Erzurum SC, Ameredes BT, Bacharier L, Calhoun WJ, Castro M, Chung KF, Clark MP, Dweik RA, Fitzpatrick AM, Gaston B, Hew M, Hussain I, Jarjour NN, Israel E, Levy BD, Murphy JR, Peters SP, Teague WG, Meyers DA, Busse WW, Wenzel SE: Characterization of the severe asthma phenotype by the National Heart, Lung, and Blood Institute's Severe Asthma Research Program. J Allergy Clin Immunol 2007, 119:405-413.

11. Peters SP, Jones CA, Haselkorn T, Mink DR, Valacer DJ, Weiss ST: Real- world Evaluation of Asthma Control and Treatment (REACT): findings from a national web- based survey. J Allergy Clin Immunol 2007, 119:1454-1461.

12. Rabe KF, Vermeire PA, Soriano JB, Maier WC: Clinical management of asthma in 1999: the Asthma Insights and Reality in Europe (AIRE) study. Eur Respir J 2000, 16:802-807.

13. Johnston SL, Sanderson G, Pattemore PK, Smith S, Bardin PG, Bruce CB, Lambden PR, Tyrrell DA, Holgate ST: Use of polymerase chain reaction for diagnosis of picornavirus infection in subjects with and without respiratory symptoms. J Clin Microbiol 1993, 31:111-117.

14. Leung TF, To MY, Yeung AC, Wong YS, Wong GW, Chan PK: Multiplex molecular detection of respiratory pathogens in children with asthma exacerbation. Chest 2010, 137:348-354.

15. Lee WM, Kiesner C, Pappas T, Lee I, Grindle K, Jartti T, Jakiela B, Lemanske RF Jr, Shult PA, Gern JE: A diverse group of previously unrecognized human rhinoviruses are common causes of respiratory illnesses in infants. PLOS ONE 2007, 2:e966.

16. Khetsuriani N, Kazerouni NN, Erdman DD, Lu X, Redd SC, Anderson LJ, Teague WG: Prevalence of viral respiratory tract infections in children with asthma. J Allergy Clin Immunol 2007, 119:314-321. 
17. Green RM, Custovic A, Sanderson G, Hunter J, Johnston SL, Woodcock AA: Synergism between allergens and viruses and risk of hospital admission with asthma: case- control study. BMJ 2002, 324:763.

18. Murray CS, Poletti G, Kebadze T, Morris J, Woodcock A, Johnston SL, Custovic A: Study of modifiable risk factors for asthma exacerbations: virus infection and allergen exposure increase the risk of asthma hospital admissions in children. Thorax 2006, 61:376-382.

19. Chauhan AJ, Inskip HM, Linaker CH, Smith S, Schreiber J, Johnston SL, Holgate ST: Personal exposure to nitrogen dioxide (NO2) and the severity of virus- induced asthma in children. Lancet 2003, 361:1939-1944.

20. Corne JM, Marshall C, Smith S, Schreiber J, Sanderson G, Holgate ST, Johnston SL: Frequency, severity, and duration of rhinovirus infections in asthmatic and non-asthmatic individuals: a longitudinal cohort study. Lancet 2002, 359:831-834.

21. Message SD, Laza-Stanca $V$, Mallia P, Parker HL, Zhu J, Kebadze T, Contoli M, Sanderson G, Kon OM, Papi A, Jeffery PK, Stanciu LA, Johnston SL: Rhinovirus- induced lower respiratory illness is increased in asthma and related to virus load and Th1/2 cytokine and IL-10 production. Proc Natl Acad Sci USA 2008, 105:13562-13567.

22. Slater L, Bartlett NW, Haas JJ, Zhu J, Message SD, Walton RP, Sykes A, Dahdaleh S, Clarke DL, Belvisi MG, Kon OM, Fujita T, Jeffery PK, Johnston SL, Edwards MR: Co- ordinated role of TLR3, RIG- I and MDA5 in the innate response to rhinovirus in bronchial epithelium. PLoS Pathog 2010, 6 : e1001178

23. Yoneyama M, Kikuchi M, Natsukawa T, Shinobu N, Imaizumi T, Miyagishi M, Taira K, Akira S, Fujita T: The RNA helicase RIG- I has an essential function in double- stranded RNA-induced innate antiviral responses. Nat Immunol 2004, 5:730-737.

24. Zhu Z, Tang W, Gwaltney JM Jr, Wu Y, Elias JA: Rhinovirus stimulation of interleukin- 8 in vivo and in vitro: role of NF- kappaB. Am J Physiol 1997, 273:L814-L824

25. Edwards MR, Haas J, Panettieri RA Jr, Johnson M, Johnston SL: Corticosteroids and beta 2 agonists differentially regulate rhinovirusinduced interleukin- 6 via distinct Cis- acting elements. J Biol Chem 2007, 282:15366-15375.

26. Spurrell JC, Wiehler S, Zaheer RS, Sanders SP, Proud D: Human airway epithelial cells produce IP- 10 (CXCL10) in vitro and in vivo upon rhinovirus infection. Am J Physiol Lung Cell Mol Physiol 2005, 289:L85-L95.

27. Zhu Z, Tang W, Ray A, Wu Y, Einarsson O, Landry ML, Gwaltney J Jr, Elias JA: Rhinovirus stimulation of interleukin- 6 in vivo and in vitro. Evidence for nuclear factor kappa B-dependent transcriptional activation. J Clin Invest 1996, 97:421-430.

28. leki K, Matsukura S, Kokubu F, Kimura T, Kuga H, Kawaguchi M, Odaka M, Suzuki S, Watanabe S, Takeuchi H, Schleimer RP, Adachi M: Doublestranded RNA activates RANTES gene transcription through cooperation of nuclear factor- kappaB and interferon regulatory factors in human airway epithelial cells. Clin Exp Allergy 2004, 34:745-752.

29. Biron CA, Nguyen KB, Pien GC, Cousens LP, Salazar-Mather TP: Natural killer cells in antiviral defense: function and regulation by innate cytokines. Annu Rev Immunol 1999, 17:189-220.

30. Kotenko SV, Gallagher G, Baurin W, Lewis-Antes A, Shen M, Shah NK, Langer JA, Sheikh F, Dickensheets H, Donnelly RP: IFN- lambdas mediate antiviral protection through a distinct class II cytokine receptor complex. Nat Immunol 2003, 4:69-77.

31. Wark PA, Johnston SL, Bucchieri F, Powell R, Puddicombe S, Laza-Stanca V, Holgate ST, Davies DE: Asthmatic bronchial epithelial cells have a deficient innate immune response to infection with rhinovirus. J Exp Med 2005, 201:937-947.

32. Cakebread JA, Xu Y, Grainge C, Kehagia V, Howarth PH, Holgate ST, Davies DE: Exogenous IFN- beta has antiviral and anti- inflammatory properties in primary bronchial epithelial cells from asthmatic subjects exposed to rhinovirus. J Allergy Clin Immunol 2011, 127:1148-1154.

33. Wark PA, Grissell $T$, Davies B, See H, Gibson PG: Diversity in the bronchial epithelial cell response to infection with different rhinovirus strains. Respirology 2009, 14:180-186.

34. Gehlhar K, Bilitewski C, Reinitz-Rademacher K, Rohde G, Bufe A: Impaired virus- induced interferon- alpha2 release in adult asthmatic patients. Clin Exp Allergy 2006, 36:331-337.

35. Bufe A, Gehlhar K, Grage-Griebenow E, Ernst M: Atopic phenotype in children is associated with decreased virus- induced interferon- alpha release. Int Arch Allergy Immunol 2002, 127:82-88.
36. Roponen M, Yerkovich ST, Hollams E, Sly PD, Holt PG, Upham JW: Toll- like receptor 7 function is reduced in adolescents with asthma. Eur Respir $J$ 2010, 35:64-71

37. Gill MA, Bajwa G, George TA, Dong CC, Dougherty II, Jiang N, Gan VN, Gruchalla RS: Counterregulation between the FcepsilonRI pathway and antiviral responses in human plasmacytoid dendritic cells. J Immunol 2010, 184:5999-6006.

38. Contoli M, Message SD, Laza-Stanca V, Edwards MR, Wark PA, Bartlett NW, Kebadze T, Mallia P, Stanciu LA, Parker HL, Slater L, Lewis-Antes A, Kon OM, Holgate ST, Davies DE, Kotenko SV, Papi A, Johnston SL: Role of deficient type III interferon- lambda production in asthma exacerbations. Nat Med 2006, 12:1023-1026.

39. Bochkov YA, Hanson KM, Keles S, Brockman-Schneider RA, Jarjour NN, Gern JE: Rhinovirus- induced modulation of gene expression in bronchial epithelial cells from subjects with asthma. Mucosal Immunol 2010, 3:69-80.

40. Lopez-Souza N, Favoreto S, Wong H, Ward T, Yagi S, Schnurr D, Finkbeiner WE, Dolganov GM, Widdicombe JH, Boushey HA, Avila PC: In vitro susceptibility to rhinovirus infection is greater for bronchial than for nasal airway epithelial cells in human subjects. J Allergy Clin Immunol 2009, 123:1384-1390.

41. DeMore JP, Weisshaar EH, Vrtis RF, Swenson CA, Evans MD, Morin A, Hazel E, Bork JA, Kakumanu S, Sorkness R, Busse WW, Gern JE: Similar colds in subjects with allergic asthma and nonatopic subjects after inoculation with rhinovirus- 16. J Allergy Clin Immunol 2009, 124:245-252.

42. Piganis RA, De Weerd NA, Gould JA, Schindler CW, Mansell A, Nicholson SE, Hertzog PJ: Suppressor of cytokine signaling (SOCS) 1 inhibits type I interferon (IFN) signaling via the interferon alpha receptor (IFNAR1)associated tyrosine kinase Tyk2. J Biol Chem 2011, 286:33811-33818.

43. Lee C, Kolesnik TB, Caminschi I, Chakravorty A, Carter W, Alexander WS, Jones J, Anderson GP, Nicholson SE: Suppressor of cytokine signalling 1 (SOCS1) is a physiological regulator of the asthma response. Clin Exp Allergy 2009, 39:897-907.

44. Fukuyama S, Nakano T, Matsumoto T, Oliver BG, Burgess JK, Moriwaki A, Tanaka K, Kubo M, Hoshino T, Tanaka H, McKenzie AN, Matsumoto K, Aizawa H, Nakanishi Y, Yoshimura A, Black JL, Inoue H: Pulmonary suppressor of cytokine signaling- 1 induced by IL- 13 regulates allergic asthma phenotype. Am J Respir Crit Care Med 2009, 179:992-998.

45. Fleming HE, Little FF, Schnurr D, Avila PC, Wong H, Liu J, Yagi S, Boushey HA: Rhinovirus-16 colds in healthy and in asthmatic subjects: similar changes in upper and lower airways. Am J Respir Crit Care Med 1999, 160:100-108

46. de Kluijver J, Grunberg K, Pons D, de Klerk EP, Dick CR, Sterk PJ, Hiemstra PS: Interleukin-1beta and interleukin-1ra levels in nasal lavages during experimental rhinovirus infection in asthmatic and nonasthmatic subjects. Clin Exp Allergy 2003, 33:1415-1418.

47. Grunberg K, Smits HH, Timmers MC, de Klerk EP, Dolhain RJ, Dick EC, Hiemstra PS, Sterk PJ: Experimental rhinovirus 16 infection. Effects on cell differentials and soluble markers in sputum in asthmatic subjects. Am J Respir Crit Care Med 1997, 156:609-616.

48. Grissell TV, Powell H, Shafren DR, Boyle MJ, Hensley MJ, Jones PD, Whitehead BF, Gibson PG: Interleukin- 10 gene expression in acute virusinduced asthma. Am J Respir Crit Care Med 2005, 172:433-439.

49. Norzila MZ, Fakes K, Henry RL, Simpson J, Gibson PG: Interleukin- 8 secretion and neutrophil recruitment accompanies induced sputum eosinophil activation in children with acute asthma. Am J Respir Crit Care Med 2000, 161:769-774.

50. Wark PA, Johnston SL, Moric I, Simpson JL, Hensley MJ, Gibson PG: Neutrophil degranulation and cell lysis is associated with clinical severity in virus- induced asthma. Eur Respir J 2002, 19:68-75.

51. Denlinger LC, Sorkness RL, Lee WM, Evans M, Wolff M, Mathur SK, Crisafi GM, Gaworski KL, Pappas TE, Vrtis RF, Kelly EA, Gern JE, Jarjour NN: Lower airway rhinovirus burden and the seasonal risk of asthma exacerbation. Am J Respir Crit Care Med 2011.

52. Ordonez CL, Shaughnessy TE, Matthay MA, Fahy JV: Increased neutrophil numbers and IL- 8 levels in airway secretions in acute severe asthma: Clinical and biologic significance. Am J Respir Crit Care Med 2000, 161:1185-1190

53. Laza-Stanca V, Stanciu LA, Message SD, Edwards MR, Gern JE, Johnston SL: Rhinovirus replication in human macrophages induces NF- kappaBdependent tumor necrosis factor alpha production. J Virol 2006, 80:8248-8258. 
54. Fraenkel DJ, Bardin PG, Sanderson G, Lampe F, Johnston SL, Holgate ST: Lower airways inflammation during rhinovirus colds in normal and in asthmatic subjects. Am J Respir Crit Care Med 1995, 151:879-886.

55. Laza-Stanca V, Message SD, Edwards MR, Parker HL, Zdrenghea MT, Kebadze T, Kon OM, Mallia P, Stanciu LA, Johnston SL: The role of IL- 15 deficiency in the pathogenesis of virus- induced asthma exacerbations. PLoS Pathog 2011, 7:e1002114.

56. Plummeridge MJ, Armstrong L, Birchall MA, Millar AB: Reduced production of interleukin 12 by interferon gamma primed alveolar macrophages from atopic asthmatic subjects. Thorax 2000, 55:842-847.

57. Ho LP, Davis M, Denison A, Wood FT, Greening AP: Reduced interleukin18 levels in BAL specimens from patients with asthma compared to patients with sarcoidosis and healthy control subjects. Chest 2002, 121:1421-1426.

58. Gern JE, Vrtis R, Grindle KA, Swenson C, Busse WW: Relationship of upper and lower airway cytokines to outcome of experimental rhinovirus infection. Am J Respir Crit Care Med 2000, 162:2226-2231.

59. Guerra S, Lohman IC, Halonen M, Martinez FD, Wright AL: Reduced interferon gamma production and soluble CD14 levels in early life predict recurrent wheezing by 1 year of age. Am J Respir Crit Care Med 2004, 169:70-76.

60. Stern DA, Guerra S, Halonen M, Wright AL, Martinez FD: Low IFN- gamma production in the first year of life as a predictor of wheeze during childhood. J Allergy Clin Immunol 2007, 120:835-841.

61. Gern JE, Brooks GD, Meyer P, Chang A, Shen K, Evans MD, Tisler C, Dasilva D, Roberg KA, Mikus LD, Rosenthal LA, Kirk CJ, Shult PA, Bhattacharya A, Li Z, Gangnon R, Lemanske RF Jr: Bidirectional interactions between viral respiratory illnesses and cytokine responses in the first year of life. J Allergy Clin Immunol 2006, 117:72-78.

62. Pauwels RA, Buist AS, Calverley PM, Jenkins CR, Hurd SS, The GOLD Scientific Committee: Global strategy for the diagnosis, management, and prevention of chronic obstructive pulmonary disease. NHLBI/WHO Global Initiative for Chronic Obstructive Lung Disease (GOLD) Workshop summary. Am J Respir Crit Care Med 2001, 163:1256-1276.

63. Hurst JR, Vestbo J, Anzueto A, Locantore N, Mullerova H, Tal-Singer R, Miller B, Lomas DA, Agusti A, Macnee W, Calverley P, Rennard S, Wouters EF, Wedzicha JA, Evaluation of COPD Longitudinally to Identify Predictive Surrogate Endpoints (ECLIPSE) Investigators: Susceptibility to exacerbation in chronic obstructive pulmonary disease. N Engl J Med 2010, 363:1128-1138.

64. Kanner RE, Anthonisen NR, Connett JE, The Lung Health Study Research Group: Lower respiratory illnesses promote FEV(1) decline in current smokers but not ex- smokers with mild chronic obstructive pulmonary disease: results from the lung health study. Am J Respir Crit Care Med 2001, 164:358-364

65. Seemungal TA, Donaldson GC, Paul EA, Bestall JC, Jeffries DJ, Wedzicha JA: Effect of exacerbation on quality of life in patients with chronic obstructive pulmonary disease. Am J Respir Crit Care Med 1998, 157:1418-1422.

66. Jenkins CR, Celli B, Anderson JA, Ferguson GT, Jones PW, Vestbo J, Yates JC, Calverley PM: Seasonality and determinants of moderate and severe COPD exacerbations in the TORCH study. Eur Respir J 2012, 39:38-45.

67. Seemungal T, Harper-Owen R, Bhowmik A, Moric I, Sanderson G, Message S, Maccallum P, Meade TW, Jeffries DJ, Johnston SL, Wedzicha JA: Respiratory viruses, symptoms, and inflammatory markers in acute exacerbations and stable chronic obstructive pulmonary disease. Am J Respir Crit Care Med 2001, 164:1618-1623.

68. Smith CB, Golden CA, Kanner RE, Renzetti AD Jr: Association of viral and Mycoplasma pneumoniae infections with acute respiratory illness in patients with chronic obstructive pulmonary diseases. Am Rev Respir Dis 1980, 121:225-232

69. Buscho RO, Saxtan D, Shultz PS, Finch E, Mufson MA: Infections with viruses and Mycoplasma pneumoniae during exacerbations of chronic bronchitis. J Infect Dis 1978, 137:377-383.

70. Papi A, Bellettato CM, Braccioni F, Romagnoli M, Casolari P, Caramori G, Fabbri LM, Johnston SL: Infections and airway inflammation in chronic obstructive pulmonary disease severe exacerbations. Am J Respir Crit Care Med 2006, 173:1114-1121.

71. Rohde G, Wiethege A, Borg I, Kauth M, Bauer T, Gillissen A, Bufe A, Schultze-Werninghaus G: Respiratory viruses in exacerbations of chronic obstructive pulmonary disease requiring hospitalisation: a case- control study. Thorax 2003, 58:37-42.

72. Qiu Y, Zhu J, Bandi V, Atmar RL, Hattotuwa K, Guntupalli KK, Jeffery PK: Biopsy neutrophilia, neutrophil chemokine and receptor gene expression in severe exacerbations of chronic obstructive pulmonary disease. Am J Respir Crit Care Med 2003, 168:968-975

73. Tan WC, Xiang X, Qiu D, Ng TP, Lam SF, Hegele RG: Epidemiology of respiratory viruses in patients hospitalized with near- fatal asthma, acute exacerbations of asthma, or chronic obstructive pulmonary disease. Am J Med 2003, 115:272-277.

74. Mohan A, Chandra S, Agarwal D, Guleria R, Broor S, Gaur B, Pandey RM: Prevalence of viral infection detected by PCR and RT- PCR in patients with acute exacerbation of COPD: a systematic review. Respirology 2010, 15:536-542.

75. Mallia P, Message SD, Gielen V, Contoli M, Gray K, Kebadze T, Aniscenko J, Laza-Stanca V, Edwards MR, Slater L, Papi A, Stanciu LA, Kon OM, Johnson M, Johnston SL: Experimental rhinovirus infection as a human model of chronic obstructive pulmonary disease exacerbation. Am J Respir Crit Care Med 2011, 183:734-742.

76. Aaron SD, Angel JB, Lunau M, Wright K, Fex C, Le Saux N, Dales RE: Granulocyte inflammatory markers and airway infection during acute exacerbation of chronic obstructive pulmonary disease. Am J Respir Crit Care Med 2001, 163:349-355.

77. Fujimoto K, Yasuo M, Urushibata K, Hanaoka M, Koizumi T, Kubo K: Airway inflammation during stable and acutely exacerbated chronic obstructive pulmonary disease. Eur Respir J 2005, 25:640-646.

78. Perera WR, Hurst JR, Wilkinson TM, Sapsford RJ, Mullerova H, Donaldson GC, Wedzicha JA: Inflammatory changes, recovery and recurrence at COPD exacerbation. Eur Respir J 2007, 29:527-534.

79. Gompertz S, O'Brien C, Bayley DL, Hill SL, Stockley RA: Changes in bronchial inflammation during acute exacerbations of chronic bronchitis. Eur Respir J 2001, 17:1112-1119.

80. Rohde G, Borg I, Wiethege A, Kauth M, Jerzinowski S, An Duong DT, Bauer TT, Bufe A, Schultz-Werninghaus G: Inflammatory response in acute viral exacerbations of COPD. Infection 2008, 36:427-433.

81. Seemungal TA, Harper-Owen R, Bhowmik A, Jeffries DJ, Wedzicha JA: Detection of rhinovirus in induced sputum at exacerbation of chronic obstructive pulmonary disease. Eur Respir J 2000, 16:677-683.

82. Quint JK, Donaldson GC, Goldring JJ, Baghai-Ravary R, Hurst JR, Wedzicha JA: Serum IP- 10 as a biomarker of human rhinovirus infection at exacerbation of COPD. Chest 2009, 137:812-822.

83. Bafadhel M, McKenna S, Terry S, Mistry V, Reid C, Haldar P, McCormick M, Haldar K, Kebadze T, Duvoix A, Lindblad K, Patel H, Rugman P, Dodson P, Jenkins $M$, Saunders M, Newbold P, Green RH, Venge P, Lomas DA, Barer MR, Johnston SL, Pavord ID, Brightling CE: Acute exacerbations of COPD: identification of biological clusters and their biomarkers. Am J Respir Crit Care Med 2011, 184:662-671.

84. Hurst JR, Wilkinson TM, Perera WR, Donaldson GC, Wedzicha JA: Relationships among bacteria, upper airway, lower airway, and systemic inflammation in COPD. Chest 2005, 127:1219-1226.

85. S Sajjan U, Ganesan S, Comstock AT, Shim J, Wang Q, Nagarkar DR, Zhao Y, Goldsmith AM, Sonstein J, Linn MJ, Curtis JL, Hershenson MB: Elastase-and LPS- exposed mice display altered responses to rhinovirus infection. Am J Physiol Lung Cell Mol Physiol 2009, 297:L931-L944.

86. Sonnenfeld G, Hudgens RW: Effect of sidestream and mainstream smoke exposure on in vitro interferon- alpha/beta production by L- 929 cells. Cancer Res 1986, 46:2779-2783.

87. Schneider D, Ganesan S, Comstock AT, Meldrum CA, Mahidhara R, Goldsmith AM, Curtis JL, Martinez Fj, Hershenson MB, Sajjan U: Increased cytokine response of rhinovirus-infected airway epithelial cells in chronic obstructive pulmonary disease. Am J Respir Crit Care Med 2010, 182:332-340.

88. Di Stefano A, Maestrelli P, Roggeri A, Turato G, Calabro S, Potena A, Mapp CE, Ciaccia A, Convacev L, Fabbri LM, Saetta M: Upregulation of adhesion molecules in the bronchial mucosa of subjects with chronic obstructive bronchitis. Am J Respir Crit Care Med 1994, 149:803-810.

89. Wilkinson TM, Donaldson GC, Johnston SL, Openshaw PJ, Wedzicha JA: Respiratory syncytial virus, airway inflammation, and FEV1 decline in patients with chronic obstructive pulmonary disease. Am J Respir Crit Care Med 2006, 173:871-876. 
90. Borg I, Rohde G, Loseke S, Bittscheidt J, Schultze-Werninghaus G, Stephan V, Bufe A: Evaluation of a quantitative real- time PCR for the detection of respiratory syncytial virus in pulmonary diseases. Eur Respir J 2003, 21:944-951.

91. Sikkel MB, Quint JK, Mallia P, Wedzicha JA, Johnston SL: Respiratory syncytial virus persistence in chronic obstructive pulmonary disease. Pediatr Infect Dis J 2008, 27:S63-S70.

92. Matsuse T, Hayashi S, Kuwano K, Keunecke H, Jefferies WA, Hogg JC: Latent adenoviral infection in the pathogenesis of chronic airways obstruction. Am Rev Respir Dis 1992, 146:177-184.

93. Meshi B, Vitalis TZ, lonescu D, Elliott WM, Liu C, Wang XD, Hayashi S, Hogg JC: Emphysematous lung destruction by cigarette smoke. The effects of latent adenoviral infection on the lung inflammatory response. Am J Respir Cell Mol Biol 2002, 26:52-57.

94. McManus TE, Marley AM, Baxter N, Christie SN, Elborn JS, Heaney LG, Coyle PV, Kidney JC: Acute and latent adenovirus in COPD. Respir Med 2007, 101:2084-2090.

95. Wang EE, Prober CG, Manson B, Corey M, Levison H: Association of respiratory viral infections with pulmonary deterioration in patients with cystic fibrosis. N Engl J Med 1984, 311:1653-1658.

96. Ong EL, Ellis ME, Webb AK, Neal KR, Dodd M, Caul EO, Burgess S: Infective respiratory exacerbations in young adults with cystic fibrosis: role of viruses and atypical microorganisms. Thorax 1989, 44:739-742.

97. Smyth AR, Smyth RL, Tong CY, Hart CA, Heaf DP: Effect of respiratory virus infections including rhinovirus on clinical status in cystic fibrosis. Arch Dis Child 1995, 73:117-120.

98. Ramsey BW, Gore EJ, Smith AL, Cooney MK, Redding GJ, Foy H: The effect of respiratory viral infections on patients with cystic fibrosis. Am J Dis Child 1989, 143:662-668.

99. Armstrong D, Grimwood K, Carlin JB, Carzino R, Hull J, Olinsky A, Phelan PD: Severe viral respiratory infections in infants with cystic fibrosis. Pediatr Pulmonol 1998, 26:371-379.

100. Wat D, Gelder C, Hibbitts S, Cafferty F, Bowler I, Pierrepoint M, Evans R, Doull I: The role of respiratory viruses in cystic fibrosis. J Cyst Fibros 2008, 7:320-328

101. de Almeida MB, Zerbinati RM, Tateno AF, Oliveira CM, Romao RM, Rodrigues JC, Pannuti CS, da Silva Filho LV: Rhinovirus C and respiratory exacerbations in children with cystic fibrosis. Emerg Infect Dis 2010, 16:996-999.

102. Zheng S, De BP, Choudhary S, Comhair SA, Goggans T, Slee R, Williams BR, Pilewski J, Haque SJ, Erzurum SC: Impaired innate host defense causes susceptibility to respiratory virus infections in cystic fibrosis. Immunity 2003, 18:619-630.

103. van Ewijk BE, van der Zalm MM, Wolfs TF, Fleer A, Kimpen JL, Wilbrink B, van der Ent CK: Prevalence and impact of respiratory viral infections in young children with cystic fibrosis: prospective cohort study. Pediatrics 2008, 122:1171-1176.

104. Sutanto EN, Kicic A, Foo CJ, Stevens PT, Mullane D, Knight DA, Stick SM, Australian Respiratory Early Surveillance Team for Cystic Fibrosis: Innate inflammatory responses of pediatric cystic fibrosis airway epithelial cells: effects of nonviral and viral stimulation. Am J Respir Cell Mol Biol 2011, 44:761-767.

105. Black HR, Yankaskas JR, Johnson LG, Noah TL: Interleukin- 8 production by cystic fibrosis nasal epithelial cells after tumor necrosis factor- alpha and respiratory syncytial virus stimulation. Am J Respir Cell Mol Biol 1998, 19:210-215.

106. Kieninger E, Vareille M, Kopf BS, Blank F, Alves MP, Gisler FM, Latzin P, Casaulta C, Geiser T, Johnston SL, Edwards MR, Regamey N: Lack of an exaggerated inflammatory response upon virus infection in cystic fibrosis. Eur Respir J 2012, 39:297-304.

107. Vareille M, Kieninger E, Alves MP, Kopf BS, Moller A, Geiser T, Johnston SL, Edwards MR, Regamey N: Impaired type I and type III interferon induction and rhinovirus control in human cystic fibrosis airway epithelial cells. Thorax

108. Holtzman M, Patel D, Kim H, You Y, Zhang Y: Hypersusceptibility to respiratory viruses as a shared mechanism for asthma, chronic obstructive pulmonary disease, and cystic fibrosis. Am J Respir Cell Mol Biol 2011, 44:739-742.

109. McCullers JA: Insights into the interaction between influenza virus and pneumococcus. Clin Microbiol Rev 2006, 19:571-582.
110. Hussell T, Cavanagh MM: The innate immune rheostat: influence on lung inflammatory disease and secondary bacterial pneumonia. Biochem Soc Trans 2009, 37:811-813.

111. Wang JH, Kwon HJ, Jang YJ: Rhinovirus enhances various bacterial adhesions to nasal epithelial cells simultaneously. Laryngoscope 2009, 119:1406-1411.

112. Ishizuka S, Yamaya M, Suzuki T, Takahashi H, Ida S, Sasaki T, Inoue D, Sekizawa K, Nishimura H, Sasaki H: Effects of rhinovirus infection on the adherence of Streptococcus pneumoniae to cultured human airway epithelial cells. J Infect Dis 2003, 188:1928-1939.

113. Sajjan U, Wang Q, Zhao Y, Gruenert DC, Hershenson MB: Rhinovirus disrupts the barrier function of polarized airway epithelial cells. Am $J$ Respir Crit Care Med 2008, 178:1271-1281.

114. Oliver BG, Lim S, Wark P, Laza-Stanca V, King N, Black JL, Burgess JK, Roth $M$, Johnston SL: Rhinovirus exposure impairs immune responses to bacterial products in human alveolar macrophages. Thorax 2008, 63:519-525.

115. Chattoraj SS, Ganesan S, Jones AM, Helm JM, Comstock AT, BrightThomas R, LiPuma JJ, I Hershenson MB, Sajjan U: Rhinovirus infection liberates planktonic bacteria from biofilm and increases chemokine responses in cystic fibrosis airway epithelial cells. Thorax 2011, 66:333-339.

116. Sajjan US, Jia Y, Newcomb DC, Bentley JK, Lukacs NW, LiPuma JJ, Hershenson MB: H. influenzae potentiates airway epithelial cell responses to rhinovirus by increasing ICAM- 1 and TLR3 expression. FASEB J 2006, 20:2121-2123.

117. Chattoraj SS, Ganesan S, Faris A, Comstock A, Lee WM, Sajjan US: Pseudomonas aeruginosa suppresses interferon response to rhinovirus infection in cystic fibrosis but not in normal bronchial epithelial cells. Infect Immun 2011, 79:4131-4145.

118. Hilty M, Burke C, Pedro H, Cardenas P, Bush A, Bossley C, Davies J, Ervine A, Poulter L, Pachter L, Moffatt MF, Cookson WO: Disordered microbial communities in asthmatic airways. PLOS ONE 2010, 5:e8578.

\section{Pre-publication history}

The pre-publication history for this paper can be accessed here: http://www.biomedcentral.com/1741-7015/10/27/prepub

doi:10.1186/1741-7015-10-27

Cite this article as: Singanayagam et al: Viruses exacerbating chronic pulmonary disease: the role of immune modulation. BMC Medicine 2012 10:27.

\section{Submit your next manuscript to BioMed Central and take full advantage of:}

- Convenient online submission

- Thorough peer review

- No space constraints or color figure charges

- Immediate publication on acceptance

- Inclusion in PubMed, CAS, Scopus and Google Scholar

- Research which is freely available for redistribution 